Belousova, A. et al. (2021). The basic principles of training future teachers to work with younger students with experience of traumatic effects, International Journal of Cognitive Research in Science, Engineering and Education (IJCRSEE), 9(3), 375384.

Original scientific paper

UDK:

316.61-057.874

37.091 .12

Received: November, 18.2021.

doi: 10.23947/2334-8496-2021-9-3-375-384

Revised: December, 12.2021.

Accepted: December, 14.2021.

Check for updates

\title{
The Basic Principles of Training Future Teachers to Work With Younger Students With Experience of Traumatic Effects
}

\author{
Alla Belousova $^{1^{*}}$ (D), Anna Grinko² (D), Olga Fedotova ${ }^{1}$ (D) Nusaiba Marachli ${ }^{\text {(D) }}$, Shiraz Alali ${ }^{\text {(D) }}$
}

\begin{abstract}
1Don State Technical University, Rostov-on-Don, Russian Federation, e-mail: belousovaak@gmail.com, fod1953@yandex.ru
${ }^{2}$ South Russian Humanitarian Institute, Rostov-on-Don, Russian Federation, e-mail: anigrin@rambler.ru

3Damascus University, Damascus, Syrian Arab Republic, e-mail:dr.n.merashli@gmail.com, Shirazalali00@gmail.com
\end{abstract}

\begin{abstract}
The article shows that the unstable situation in the world leads to possible armed conflicts, affecting primarily children, experiencing various traumatic consequences. Such a situation arises in post-conflict regions and creates a need for teachers who possess the necessary competencies when teaching children with experience of traumatic effects. The purpose of the article is to study the state and trends in the development of psychological and pedagogical issues related to the use of collaborative learning technologies to form the psychological culture of future teachers in order to further work with children with experience of traumatic effects. It is shown that the analysis of the formation and development of the problems of group psychological corrective work is grounded on the basic principles identified by representatives of various directions. The authors propose to build the training of future teachers on the basis of a model of joint thinking for the subsequent organization of teachers' interaction with children who have experience of traumatic effects. The authors analyzed the basic principles of group psychologically corrective work from the point of view of the possibilities of organizing joint thinking. The basic principles of the organization of training of future teachers were highlighted, their meaningful characteristics for the purposes of organizing joint thinking were given. A comparison of the principles of group psychological corrective work and the principles of the organization of joint thinking of future teachers is carried out. Their correlation and the importance of using joint thinking in organizing the training of future teachers and for conducting psychologically corrective work with children are shown.
\end{abstract}

Keywords: principles of teaching, psychological corrective work, collaborative thinking, junior schoolchildren, traumatic impact, future teacher.

\section{Introduction}

The current situation of world social development is characterized by a high level of instability associated with the permanently emerging armed conflicts in various areas of the world space. These conflicts differ in nature, but they have similar consequences for civilians and especially for children. As is known, the child's psyche is characterized by impressionability, the dominance of perception processes in the structure of intelligence (Piaget, 2001) and consciousness (Vygotsky, 2005). These features lead to the fact that the perception of conflict situations, military actions that threaten the life of a child, his relatives or other people, have a negative impact on the child, having long-term consequences in the further adaptation of a person to new conditions.

Children who find themselves in conditions of armed conflict experience various traumatic events: a threat to their physical health or the health of relatives and friends, the death of people, which lead to a fairly wide range of psychological disorders - a change in the image of "l", loss of identity, transformations of the image of the world and lifestyle. In psychology, such consequences are described by the term "mental trauma", denoting experiences caused by severe events that traumatize the psyche (Burlakova, 2019). As shown by L. C. Terr, the following features are characteristic of children who have experienced traumatic effects: depressing obsessive memories of an event; "repetitive reproduction of a traumatic event in games, dreams, visual images; special fears concerning trauma; changing attitudes towards peers, adults, various spheres of life", to the future (Terr, 1991). Yul and Williams (1992) also emphasize that children begin to study poorly, their emotional and behavioral inhibition, the desire to be with their 
parents is noted; severe anxiety, increased alertness and suspicion.

Researchers note (Osofsky, Osofsky and Harris, 2007; Masten and Obradovic, 2008; Masten and Osofsky, 2010) that school acts as one of the most important factors that have a positive and constructive impact on the restoration of a child's normal life, on the development of hislher relationships with peers and reference adults, on the development of personal potential in the manifestation of leadership, support. Scientists also emphasize the role of groups or communities that have a health-improving effect on the child (Betancourt and Khan, 2008; Masten and Obradovic, 2008; Norris et al., 2008).

The organization of educational activities and psychological support for younger schoolchildren with traumatic experiences involves the use of the principles of group correction. There is a fairly large body of work devoted to various aspects of group correction (A. Adler, C.G. Jung, J. Kelly, J. L. Moreno, F. Perls, K. Rogers, E. Watkins).

According to these ideas, group psychological correction is the most effective way to eliminate the negative experience acquired during a person's life and the experience of psychological traumatic effects (Leitz, 2017; Moreno, 2001; Rudestam, 2006). Researches on psychological correction (Rudestam, 2006) claim that group itself can be considered as a psychotherapeutic factor. Although it is obvious that with individual interaction, a child receives more concentrated attention from a psychologist, the advantages of the group form of work cannot be overestimated.

The analysis of the psychological features of the consequences of armed conflicts for children attracts the special attention of psychologists and educators, both from the point of view of the need to help children with experience of traumatic effects, and from the point of view of helping teachers interacting with such children in the educational process (Fedotova, 2015; Fedotova and Latun, 2015). In this case, a separate task is to analyze the issues of preparing future teachers to work with children who have experienced the traumatic effects of military operations.

\section{Materials and Methods}

The purpose of the article is to study the state of psychological and pedagogical issues related to the use of collaborative learning technologies to form the psychological culture of future teachers in order to work with children with experience of traumatic effects.

The object of research is scientific texts that reveal the results of research on various aspects of the problem of training future teachers who are in demand to work with children who have experienced the traumatic effects of military operations.

The hypothesis of the study. We proceed from the assumption that the formation of the psychological culture of future teachers, necessary for subsequent work with children with traumatic effects experience, is associated with the use of co-learning technologies in the form of the organization of joint thinking.

The hypothesis implemented will be based on the analysis of existing theoretical and empirical studies concerning group psychological correction work and the principles of organizing joint training of future teachers. This will make it possible to highlight the principles of teaching of joint thinking when preparing future teachers to work with children who have experienced the traumatic effects of military operations.

Research methods - analysis, synthesis, generalization, abstraction, comparative analysis (Fedotova and Chigisheva, 2015), content analysis, interpretation.

Content analysis has many options, we used the option associated with the allocation of the fixed unit of analysis (Titscher et al., 2009).

The object of the study was publications on Collaborative learning and related research from 2011 to 2021, posted in eLIBRARY and Scopus.

The sources of the research are publications and materials presented in scientific and analytical databases. We turned to the publications presented in the Scopus, the largest international database of scientific publications, and in the scientific electronic library eLIBRARY.RU, the Russian information and analytical database - Russian Science Citation Index (RSCI).

The following categories were taken as a fixed unit: "Collaborative learning", "Collaborative thinking", "Collaborative thinking activity", "Collaborative problem solving in learning", "Collaborative problem solving in a group", which were mentioned in the titles of publications. We assumed that the significance of this problem in the subject field of science lies behind the frequency of distribution of publications on this issue. 


\section{Results}

Based on these categories of content analysis, we studied the frequency of reflection of problems associated with collaborative learning and its psychological and pedagogical analogues: "Collaborative learning", "Collaborative thinking", "Collaborative thinking activity", "Collaborative problem solving in learning", "Collaborative problem solving in a group", from 2011 to the present.

This period is chosen as a time period within which, according to our assumption, this issue has become more in demand. The results are presented in Figure 1.

Based on thematic search queries in the Scopus and the Russian Science Citation Index, it was found that for the period 2011 - 2021 there is a progressive increase in the number of publications on the problems of the collaborative learning. According to the results of queries in the Scopus database, the number of publications on the problem of collaborative learning has almost doubled: if in 2011 the Scopus database shows 2483 publications, then in November 2021 - the number of publications is already 5453. According to the scientific electronic library eLIBRARY.RU, the situation is even more indicative: in 2011, the number of publications - 104, in 2021 - 655. Thus, in our opinion, the results indicate a general global trend associated with the dissemination and development of various forms of collaborative learning.

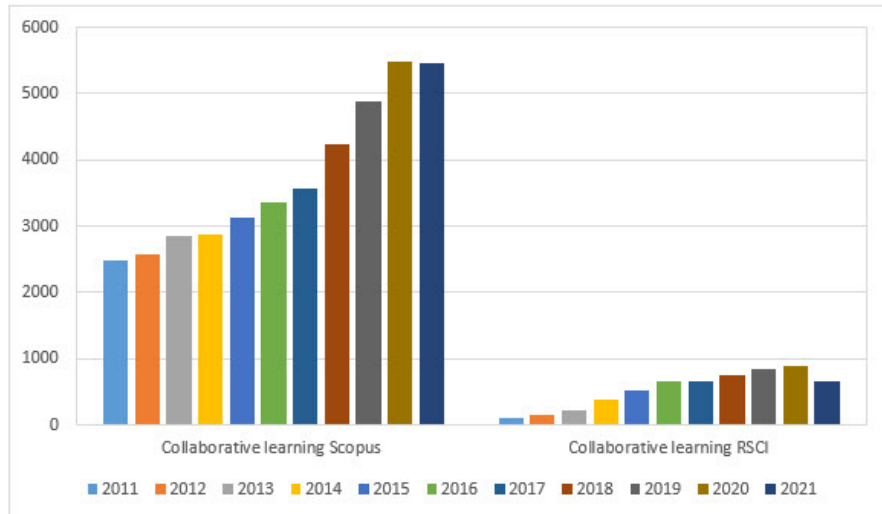

Figure 1. Number of publications in the Scopus and the Russian Science Citation Index databases in the category "collaborative learning" by year

Our next step was to try to understand what tendencies exist in relation to the problem of the development of thinking and mental activity in collaborative learning. In accordance with our ideas (Belousova, 2002; 2010; 2020), the thinking that develops in collaborative learning can be described in terms collaborative thinking, collaborative thinking activity, collaborative problem solving in learning, collaborative problem solving in a group. It seems to us that behind these concepts there is one objective reality, namely, collaborative thinking. We believe that the catalog of possible names is associated with the focus of the authors' research activities aimed at various aspects of the problem of collaborative thinking.

We were interested to see how publications related to collaborative learning are represented in authoritative databases: "Collaborative thinking", "Collaborative thinking activity", "Collaborative problem solving in learning", "Collaborative problem solving in a group", from 2011 to the present. The results are presented in Figure 2.

Using topical searches in the Scopus and the Russian Science Citation Index, we also found an increase in the number of publications on the problems of the collaborative thinking. If we combine the number of publications by categories related to collaborative thinking, we get the following results. In the Scopus database, the number of publications on the problem of collaborative thinking has almost doubled: in 2011, 501 publications, in November 2021 - 1022. According to the Russian Science Citation Index: in 2011 - 27 publications, in 2021 - 169. In this case, there is a correspondence a general global trend associated with interest in the development of various forms of collaborative thinking. 
Belousova, A. et al. (2021). The basic principles of training future teachers to work with younger students with experience of traumatic effects, International Journal of Cognitive Research in Science, Engineering and Education (IJCRSEE), 9(3), 375384.

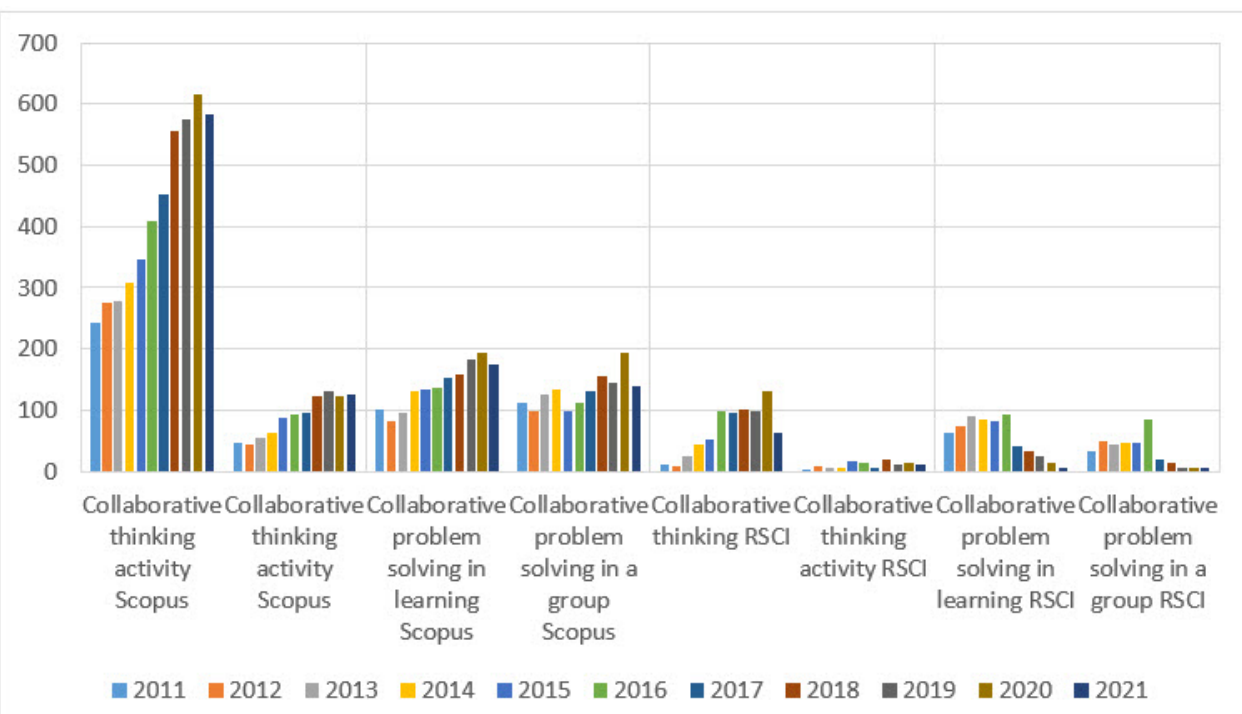

Figure 2. Distribution of publications in the Scopus and the Russian Science Citation Index (RSCI) databases in the categories "Collaborative thinking", "Collaborative thinking activity", "Collaborative problem solving in learning", "Collaborative problem solving in a group" by year

Based on: 1. The analysis of the distribution of publications on the development of collaborative learning and collaborative thinking; 2 . Our assumption that the formation of the psychological culture of future teachers to work with children with trauma experience is associated with the use of collaborative learning technologies and the development of collaborative thinking, we consider it appropriate to conduct a comparative analysis of studies related to group psycho-correctional work. Such an analysis is necessary in order to show that the possibilities for the development of collaborative thinking are laid down in the postulates of group correctional work. This will give us the opportunity to correlate the principles of group correction and the principles of teaching collaborative thinking when preparing future teachers to work with children who have experienced the traumatic effects of military operations.

$\mathrm{K}$. Rudestam highlighted some advantages of group work in comparison with other forms of psychological correction (Rudestam, 2006). The first advantage, which experts note, is that a person is constantly surrounded by people, he is constantly affected by the assessments of partners, social assessments of others and relatives, conformism. The correction groups reveal which factors had a direct impact on the views and behavior of the individual. Awareness and comprehension of the effects on the personality leads to a therapeutic effect. At the same time, the experience gained in the created group, the psycho-correction group, is usually transferred to the outside world (Rudestam, 2006).

The second important advantage of the group is the possibility of reflecting a problematic situation for a person by other members of the group, which leads to the formation of each participant's own vision of this situation, their own solution, their own assessments. This situation allows you to get support from participants who have similar problems. In a group, each participant feels accepted by others and accepting others, feels self-confidence and trusts others, shows care and feels care from others, provides help and receives it. Such interaction contributes to the formation of positive assessments of one's image of the world (Rudestam, 2006).

The third advantage is that a group member can observe from the outside active group members who have similar problems, thereby having the opportunity not to get involved in the course of events, but to assess the situation from the outside and get a more complete experience to assess their emotions and actions. A multitude of feedbacks creates a reflection of the personality in many angles simultaneously, allowing it to evaluate its own behavior and attitudes (Rudestam, 2006).

The fourth advantage is that the group promotes personal growth. Conditions are created in the group where the personality of the participants inevitably tends to self-exploration and introspection. Often people know what they want, but they are afraid of a negative assessment of others and do not declare their needs, aspirations and desires, thereby not allowing themselves to be realized. In group interaction, each attempt at self-disclosure and self-change of a group member causes positive assessments from other group members, which contributes to an increase in the individual's self-esteem (Rudestam, 2006).

Currently, there are many methods of group psychological correction. The main ones are traditionally considered to be gestalt groups, body therapy groups, transactional analysis, behavioral therapy and 
Belousova, A. et al. (2021). The basic principles of training future teachers to work with younger students with experience of traumatic effects, International Journal of Cognitive Research in Science, Engineering and Education (IJCRSEE), 9(3), 375384.

psychological drama therapy (Rudestam, 2006).

Without a doubt, each of these directions is effective in its own way, but the choice of direction remains with the specialist, who can integrate the directions within the framework of the tasks and goals that helshe faces in order to remove the negative consequences of traumatic effects.

\section{Discussions}

In the broadest sense, representatives of almost all directions consider group psychological correction as a process of interaction of participants in which group members can solve various tasks (Rudestam, 2006).

There is a fairly large body of work that examines changes in personality, cognitive processes, emotional characteristics, patterns of behavior that are the result of group correctional work.

However, the specificity of the material in this article is aimed at the opportunity to consider the principles of teaching future teachers when working with younger schoolchildren with traumatic effects experience. It seems possible for us to consider the principles of training future teachers to work with younger schoolchildren with experience of psychotrauma from the point of view of the possibility of organizing various forms of joint thinking. Studies show (Barron, 2003; Belousova and Grinko, 2010; 2016; Belousova and Nurmukhamedov, 2010; Belousova and Pavlova, 2013; Chi, 2009; Chi and Menekse, 2015; Craig, Chi and and VanLehn, 2009; Dautov et al., 2019; 2021; Ermak, 2013; Heyman, 2008; Johnson and Johnson, 2013; Nurmukhamedova, 2011), collaborative thinking is an effective platform in which cooperation, mutual activity, dialogism, cognitive processes develop, meanings change, dynamic processes occur in values, self-assessments, evaluation of others. And it seems to us that joint thinking as a meaningful platform on which the training of future teachers is based can also be expanded to the introduction into practice of the educational process of younger schoolchildren with experience of traumatic effects.

The following considerations can be identified, based on which we consider it possible to correlate the norms and principles of group correctional work and implement it as an organization of joint thinking.

First of all, as emphasized by Craig and Bokum (2019), the age of middle childhood, or primary school age (Elkonin, 1997), is characterized by intensive development of thinking, its logic, characteristic of the stage of specific operations (Piaget, 2001; Craig and Bokum, 2019); the development of theoretical thinking (Davydov, 2001). Thus, the thinking of children of primary school age develops intensively during this age period.

The next factor influencing is the child's participation in school education (Craig and Bokum, 2019), which has a multidimensional effect on him, helping to express himself and develop cognitive processes, personality, social skills, adapt to the requirements of others. Osofsky, Osofsky and Harris, 2007; Masten and Obradovic, 2008; Masten and Osofsky, 2010 also the health-improving role of schooling for children was emphasized. In accordance with the views of Elkonin (1997), in primary school age, educational activity is leading, major psychological changes of personality occur in it and mental processes are rebuilt.

In this regard, we consider it possible to say that the implementation of measures to correct psychological traumatic effects may include the entire educational activity of a younger student, and not just a separate cycle of remedial classes with them.

It can be said that the process of group correction when working with younger schoolchildren implies a change in their attitude to the experience of psychotrauma, a change in psychological characteristics and qualities. It is known that any action is an expression of a holistic personality: a person is realized in the world, performing actions together with others, in a group of schoolchildren, in an atmosphere of goodwill, this process proceeds faster, since joint activity is included in the dynamics. In our opinion, correctional work in the group will acquire new opportunities if it is organized as a joint problem-solving activity. Thinking is one of the highest mental processes through which a person not only finds a solution, but it is such a process that involves the whole person, hislher personal aspirations, thanks to which a person in the process of thinking is able to go beyond the actual needs, realizing his/her higher aspirations, needs for self-development and self-actualization. The principles of group psychological correction proposed by Moreno (2001), make this process fruitful and corrective (K. Levin, K. Rogers, I. Yalom, etc.). Thus, when organizing group correctional work in the form of joint thinking, two determinants are included that can change a person's attitude to events, change hislher psychological characteristics - this is group correction and joint activity.

Consider the consolidation of the principles of group correction and joint activities. The main four principles of group correction proposed by Ja. Moreno at the beginning of the last century, and currently 
Belousova, A. et al. (2021). The basic principles of training future teachers to work with younger students with experience of traumatic effects, International Journal of Cognitive Research in Science, Engineering and Education (IJCRSEE), 9(3), 375384.

remain relevant and in demand in group psychological correction (Leitz, 2017).

One of the most important principles of group psychological correction proposed by Ja. Moreno is that "each individual - and not only the therapist - can influence another individual as a therapeutic agent, any group - as a therapeutic agent on another group" (Moreno, 2001). This principle confirms the position of scientists (Betancourt and Khan, 2008; Masten and Obradovic, 2008; Norris et al., 2008) that the study group of younger schoolchildren, as a small social group, has a therapeutic and psychologically correctional effect on its participants.

The next principle is that "group psychocorrection is a psychotherapeutic method that strives for the most optimal grouping of members. This method contributes, if necessary, to the regrouping of members, bringing the constellation of the group into line with the spontaneous motives and sympathies of its members" (Moreno, 2001). During the work of the psycho-correction group, the participants solve the tasks set, receive new information and rethink the existing knowledge. Entering information into the image of the world is one of the fundamental processes that can influence the self-development and self-organization of the individual (Klochko and Galazhinskiy, 1999; Belousova, 2002; 2010). At the same time, in accordance with the concepts of the theory of psychological systems (Klochko and Galazhinskiy, 1999; Belousova, 2010) opportunities to interact are realized for the corresponding opposites. In relation to the psycho-correction group, this means that the younger student perceives from the outside world, from communication and interaction with other members of the group the information that corresponds to him. This process of perceiving information, fitting it into the image of the world and the consciousness of schoolchildren begins from the moment they accept the meanings and values of the people who surround them. The problem of conformity has been considered in many psychological theories: K. Levin considered it with respect to the attraction of objects for a person (Levin, 2019). Moreno (2001) analyzed the correspondence of group members, considering the dynamic processes of attraction and rejection in relation to people to each other as the main ones in their interaction. In his opinion, it is the dynamic processes of attraction and rejection that are decisive in the process of grouping and regrouping members, and it is this group that is the most promising for psychological corrective work.

The third principle "group psychocorrection is therapy not only for one individual who finds himl herself in the center of attention due to difficulties of adaptation and integration, but also for the whole group and all individuals who are associated with it" (Moreno, 2001). Under the influence of one partner, the meanings and values of objects and surrounding people change for the other, new emotions are formed, attitudes change, new attitudes are generated, connecting with emotions. All this can cause the appearance of psychological neoplasms, leading to the emergence of new emotions, changes in the image of the Self, rethinking of previous experience (Yalom, 2001).

The fourth principle states that "the purpose of group psychotherapy is: a) promoting the integration of the individual as opposed to the uncontrolled forces that surround himlher: this is achieved through the individual's study - for example, with the help of sociometric analysis - of this immediate environment; b) facilitating the integration of the group. This rapprochement of the parties - the individual and the group - contributes to their mutual integration. The fundamental rule is "spontaneous and free interaction" between patients, as well as between patients and therapists" (Moreno, 2001). In the conditions of a psychocorrective group, a common semantic field is created (Vygotsky, 2005), a common psychological situation (Belousova, 2010), in which new formations of a common worldview are generated, acting in the conditions of "here and now" in the form of common meanings and values (Belousova, 2010). The formation of a common psychological situation as a result of group interaction forms correspondences in the worldview and contributes to the generation of a common part of the image of the world of each participant. The formed neoplasms are transmitted through semantic channels during group communication and interaction from one group member to another, due to which significant information is integrated into the image of the world of each participant (Belousova, 2010; Suroedova, 2019).

The analysis of the principles of group psychocorrection leads us to formulate the principles of teaching future teachers who can implement the basic ideas of psychocorrection in educational activities with younger schoolchildren. At the same time, the use of such methods requires taking into account specific psychological and pedagogical principles (Abakumova et al., 2019; Verbitsky, 2017), which can become the basis for training future teachers to realize the possibilities of group correctional work with younger schoolchildren through the development of joint thinking:

1. the principle of joint activity;

2. the principle of modeling;

3. the principle of dialogicity;

4. the problem principle;

5. the principle of gaming activity, or gamification. 
Belousova, A. et al. (2021). The basic principles of training future teachers to work with younger students with experience of traumatic effects, International Journal of Cognitive Research in Science, Engineering and Education (IJCRSEE), 9(3), 375384.

The principle of joint activity assumes that the training of future teachers is carried out through the organization of various forms of joint activity. This can be an activity using critical thinking technologies, project methods, interactive teaching methods. The conditions for organizing various forms of joint activity (group methods, work in pairs, etc.), on which innovative teaching methods are built, fully create conditions for the development of subjectivity, the formation of readiness and ability for self-development and self-improvement, the development of creativity and the potential for self-realization of the individual (Abakumova et al., 2019).

The principle of joint activity creates the most favorable conditions for the development of the personality of each student:

1. organization of educational activities as a group and joint, during which the situation of discovery and finding of knowledge is modeled, which corresponds to the formation of readiness for uncertainty, the development of the ability to anticipate;

2. educational activities are carried out in the form of joint projects, involving their active interaction, which implies the development of the ability to cooperate, to act together in new situations;

3. trusting relationships between the teacher and the trainees, contributing to the formation of tolerance to uncertainty, abilities to justified risk, responsibility, the need for self-realization, achievement motivation, reflexivity, creativity of participants;

4. encouragement from the teacher and other members of the group, contributing to identification with the group, helping the student to believe in his own strength, and, consequently, on the basis of this, to form the readiness of the individual for the rapidly coming changes in society.

The idea of collaborative learning corresponds to the main directions of innovative approaches to learning presented in the psychology of education (Ahonen and Harding, 2018; Belousova, 2020; Care, Scoular and Griffin, 2016; Chen et al., 2019; Dillenbourg et al., 1996; Griffin, 2017; Harding et al., 2017; Johnson and Johnson, 2013; Lioe, Fai and Hedberg, 2006; Yuan, Xiao and Liu, 2019).

The principle of modeling involves recreating situations, the analysis and reflection of which contribute to the development of joint thinking skills. To implement this principle, it is necessary to create situations of interpersonal interaction that stimulate discussion between participants and the development of joint thinking (Abakumova et al., 2019; Belousova, 2010; Verbitsky, 2017).

The principle of dialogicity is aimed at developing the mutual orientation of communication processes going from one participant to other partners. The conditions of dialogue and communication create the necessary prerequisites and opportunities for the development of each participant in the discussion. Dialogue or polylogue, in the form of which joint thinking is carried out, involves the use of verbal (verbal) and non-verbal means of communication. Verbal communication is the medium through which participants in the educational process transmit to each other formed hypotheses, plans, intentions, goals, etc. Thanks to verbal communication, meaningful changes are made in solving problems, participants' thinking develops through the accumulation and discovery of new knowledge (Belousova, 2010; Verbitsky, 2017).

Nonverbal means of communication perform an important function in dialogue and polylogue: thanks to them, thinking develops, intellectual activity is formed, the effectiveness of educational activities increases due to the transmission of the meaning of the ideas generated by the participants. In this regard, for the organization of training, it is extremely important to organize not only verbal, informational interaction, but also to create a certain emotional atmosphere that would allow participants of joint thinking to understand each other, stimulate the development of intellectual activity (Abakumova, Kagermazova and Ermakov, 2016; Suroedova, 2019).

In the process of communication, by transmitting information to each other about solving problems, participants change each other's ideas about the course of the solution, about the subject being studied, and at the same time change and correct ideas about the teacher, communication and solution partners, ideas about themselves. Thus, there is an expansion of horizons, detailing the image of the world, the situation, the transformation of their own positions and the positions of partners.

The problem principle means that the content of training is constructed as a statement of a problems set (the detection of the incomprehensible, unknown or even paradoxical for the trainees). In the process of solving these problems, there is a clash of different points of view. In this case, the teacher performs the functions of posing problems to students and at the same time is an active participant in the dialogue, helps each person to express their thoughts, hypotheses to others, even if they are erroneous and weird (Belousova, 2010; Verbitsky, 2017).

This moment seems extremely important already due to the fact that, according to the ideas (Vygotsky, 2005; Davydov, 2001; Leontiev, 2004), the learner comprehends, internalizes concepts in the process of a detailed external dialogue with others, which gradually becomes an internal dialogue, that is, a discussion and dispute between a person and himself. Internally, speech utterances are reduced, 
curtailed and become understandable only to the person himself. Quite often these individualized representations are not correct or not accurate. In order to change or rebuild these ideas, they need to be externalized, deployed in terms of direct communication and problem solving, i.e., reflexed and brought out. An outwardly detailed dialogue is the main condition for the exteriorization of internal schematisms of thinking.

The principle of gaming activity, or gamification, emphasizes the need for students to reproduce the real practical activities of people. This principle involves the practical training of students in performing certain actions, the development of creative thinking, the formation of practical skills and abilities. But the most valuable thing is that in the situation of modeling a practical situation in the conditions of practical activity (cognitive or other), certain qualities, personality traits are transformed, hislher position, assessments, ideas change, the desire for self-development develops (Belousova, 2010; Verbitsky, 2017).

\section{Conclusions}

Thus, generalizing, we can say that the principles of group psychological correction, highlighted by Ja. Moreno, correlate with the principles of the development of joint thinking (Abakumova et al., 2019; Belousova, 2002; 2010; Verbitsky, 2017).

The idea of co-education is currently extremely popular; it is implemented in various models. The article presents a model based on the use of collaborative thinking as a solution to problems. In our opinion, training based on the joint solution of tasks or problems by participants in the educational process most corresponds to the essence of the profession of a teacher, designed to help, interact and communicate with students, parents, colleagues, representatives of various social strata and groups.

In this case, the organization of training of future teachers as joint thinking contributes to the development of competencies, soft skills, aimed primarily at improving the skills of interaction and communication with students.

This becomes especially important for children who have traumatic experience. A teacher who has passed the school of joint thinking training receives: skills of interaction with people, skills of cooperation in solving problems; experience of interaction and communication; experience of perception, listening and understanding of another person; experience of reflection about another person.

It can be said that such a teacher is prepared to organize educational interaction with children who have experienced traumatic effects, and is set up to organize interaction with them in the form of cooperation and joint activities, group work to solve problems, which is the most effective and constructive factor for children to adapt to normal life and recovery.

\section{Acknowledgements}

The article was prepared within the framework of the project "Development and implementation of a comprehensive technology for training specialists to work with primary school students with experience of psychotraumatic feelings", carried out jointly with the University of Damascus (Agreement number: 13.2251.21.0068. Lot code: 2021-2251-PP4-0011). The results were obtained with the financial support of the Russian Federation represented by the Ministry of Science and Higher Education of the Russian Federation (Agreement No. 075-15-2021-1014).

\section{Conflict of interests}

The authors declare no conflict of interest.

\section{References}

Abakumova, I. V., Belousova, A. K., Zorina, E. S., Maksimovich, E., Nikolaeva, E. A., Nurmukhamedova, I. V., Stošić, L., Fedotova, O. D. (2019). Психолого-педагогические основы инновационных методов обучения в высшей школе [Psychological and pedagogical foundations of innovative teaching methods in higher school]. Moscow, "Publishing House" KnoRus. Retrieved from https://www.elibrary.ru/item. asp?id=42466867

Abakumova, I. V., Kagermazova, L.Ts, \& Ermakov, P. N. (2016). Технологии направленной трансляции смыслов в практике учебного процесса [Technologies of directed translation of meanings in the practice of the educational process]. Moscow, Credo. Retrieved from https://www.elibrary.ru/item.asp?id=25571204

Ahonen, A., \& Harding, S. M. (2018). Assessing online collaborative problem solving among school children in finland: a case study using ATC21S TM in a National Context. International Journal of Learning, Teaching and Educational Research, 17(2), 138-158. https://doi.org/10.26803/ijlter.17.2.9 
Belousova, A. et al. (2021). The basic principles of training future teachers to work with younger students with experience of traumatic effects, International Journal of Cognitive Research in Science, Engineering and Education (IJCRSEE), 9(3), 375384.

Barron, B. (2003). When smart groups fail. Journal of the Learning Science. 12(3), 307-359. https://doi.org/10.1207/ S15327809JLS1203 1

Belousova, A. K. (2010). Initiation of collaborative thinking activity self-organization. Saarbrücken: LAP LAMBERT.

Belousova, A. (2020). Functions of Participants in the Collaborative Solution of Thinking Problems. International Journal of Cognitive Research in Science, Engineering and Education (IJCRSEE), 8(Special issue), 29-36. https://doi. org/10.23947/2334-8496-2020-8-SI-29-36

Belousova, А. К. (2002). Самоорганизация совместной мыслительной деятельности [Self-organization of Collaborative thinking activity]. Rostov-on-Don: Publishing house of the Rostov Pedagogical University. Retrieved from https://www. elibrary.ru/item.asp?id=23550556

Belousova, A. K, \& Grinko, A. А. (2010). Личностные оценки как проявление смысловых установок в процессах мышления о другом человеке [Personal assessments as a manifestation of semantic attitudes in the processes of thinking about another person. News of the Southern Federal University. Pedagogical sciences]. Известия Южного федерального университета. Педагогические науки. 11, 129-136. Retrieved from https://www.elibrary.ru/item.asp?id=15553568

Belousova, A. K, \& Grinko, A. A. (2016). Development of thinking about themselves by participants of group psychotherapy. International Journal of Psychology. 51. S1. 183. https://doi.org/10.1002/ijop.12299

Belousova, A. K, \& Nurmukhamedova, I. V. (2010). Компоненты совместного мышления в педагогической деятельности учителей [Components of Collaborative thinking in the pedagogical activity of teachers. News of the Southern Federal University. Pedagogical sciences]. Известия Южного феедерального университета. Педагогические науки. 6 , 77-84. Retrieved from https://www.elibrary.ru/item.asp?id=15123239

Belousova, A. K., \& Pavlova, T. V. (2013). Features of Communicative Sphere of Preschool Children Collaborative Thinking Activity. International Journal of Cognitive Research in Science, Engineering and Education (IJCRSEE), 1(1), 1-4. Retrieved from https://www.ijcrsee.com/index.php/ijcrsee/article/view/55

Betancourt, T. S., \& Khan, K. T. (2008). The mental health of children affected by armed conflict: protective processes and pathways to resilience. International review of psychiatry (Abingdon, England), 20(3), 317-328. https://doi. org/10.1080/09540260802090363

Burlakova, N. S. (2019). Угрозы психологическому благополучию и развитию ребенка в условиях крупных антропогенных, природных и социогенных бедствий [Threats to the psychological well-being and development of the child in conditions of major anthropogenic, natural and sociogenic disasters. In: Tkhostov A. Sh. Rasskazova E. I. (eds) Guide to health psychology]. Руководство по психологии здоровья. (Ред.) Тхостов А. Ш. Рассказова E. И. Moscow, Moscow University Press. 393-424. Retrieved from https://msupress.com/catalogue/books/book/ rukovodstvo-po-psikhologii-zdorovyal

Care, E., Scoular, C., \& Griffin, P. (2016). Assessment of collaborative problem solving in education environments. Applied Measurement in Education, 29(4), 250-264. https://doi.org/10.1080/08957347.2016.1209204

Chen, L., Yoshimatsu, N., Goda, Y., Okubo, F., Taniguchi, Y., Oi, M. \& Yamada, M. (2019). Direction of collaborative problem solving-based STEM learning by learning analytics approach. Research and Practice in Technology Enhanced Learning, 14(1), 1-28. https://doi.org/10.1186/s41039-019-0119-y

Chi, M. T. H. (2009). Active-Constructive-Interactive: A Conceptual Framework for Differentiating Learning Activities. Topics in Cognitive Science. 1, 73-105. https://doi.org/10.1111/j.1756-8765.2008.01005.x

Chi, MTH, \& Menekse, M (2015). Dialogue patterns in peer collaboration that promote learning. In: Resnick, L, Asterhan, C, Clarke, S (eds) Socializing Intelligence through Academic Talk and Dialogue. Washington, DC: American Educational Research Association, pp. 253-264. https://doi.org/10.3102/978-0-935302-43-1 21

Craig, G, \& Bokum, D. (2019). Психология развития [Developmental psychology]. St. Petersburg: Peter. https://www.labirint. $\mathrm{ru} / \mathrm{books} / 524531 /$

Craig, S. D., Chi, M. T., \& VanLehn, K. (2009). Improving Classroom Learning by Collaboratively Observing Human Tutoring Videos while Problem Solving. Journal of Educational Psychology. 101, 779-789. https://doi.org/10.1037/a0016601

Dautov, D. F., Lomova N. V., Rashchupkina Y. V., Nikolenko O. F, \& Tushnova J. A. (2019). Cognitive Maps of Participants in Joint Mental Activity. In: Proceedings of the $2^{\text {nd }}$ International Conference on Education Science and Social Development (ESSD 2019). 210-214. https://doi.org/10.2991/essd-19.2019.47

Dautov, D. (2021). The Ratio of Verbal and Nonverbal Components of Individual Cognitive Maps as a Reflection of the Collaborative Thinking Activity of Its Participants. International Journal of Cognitive Research in Science, Engineering and Education (IJCRSEE), 9(1), 51-62. https://doi.org/10.23947/2334-8496-2021-9-1-51-62

Davydov, V. V. (2001). Виды обобщения в обучении [Types of generalization in learning]. Moscow: Pedagogical Society of Russia. Retrieved from https://www.koob.ru/davidov_vasili/

Dillenbourg, P., Baker, M., Blaye, A., \& O’Malley, C. (1996). The evolution of research on collaborative learning. In: E. Spada \& P. Reiman (eds.) Learning in humans and machine: Towards an interdisciplinary learning science. Oxford: Elsevir. 189-211. Retrieved from https://doi.org/10.1007/978-1-4020-9827-7_1

Elkonin, D. B. (1997). Психическое развитие в детских возрастах: избранные психологические труды [Mental development in childhood: selected psychological works]. Moscow, Institute of Practical Psychology; Voronezh, NPO MODEK. Retrieved from https://www.koob.ru/elkonin_d_b/men_development

Ermak V. V. (2013). Особенности изменений смыслового содержания субъективной картины болезни у участников групповой психологической коррекции [Features of changes in the semantic content of the subjective picture of the disease among participants in group psychological correction. University Bulletin (State University of Management)]. Вестник Университета (Государственный университет управления). (18), 236-240. Retrieved from https://cyberleninka.ru/article/n/osobennosti-izmeneniy-smyslovogo-soderzhaniya-subektivnoy-kartiny-bolezni-uuchastnikov-gruppovoy-psihologicheskoy-korrektsii

Fedotova, O. (2015). Modern Education in the Framwork of Affirmatine and Non-Affirmative Approaches. In: Procedia - Social and Behavior Sciences. 2015. 180, 55-60. https://doi.org/10.1016/j.sbspro.2015.02.085

Fedotova, O, \& Chigisheva, O. (2015). Comparative Analysis: Methodological Optics in the Ideological Context. International perspectives on Education and Society Series. Comparative Sciences: interdisciplinary approaches. (26), 57-82. https://doi.org/10.1108/S1479-367920140000026003 
Belousova, A. et al. (2021). The basic principles of training future teachers to work with younger students with experience of traumatic effects, International Journal of Cognitive Research in Science, Engineering and Education (IJCRSEE), 9(3), 375384.

Fedotova, O, \& Latun, V. (2015). Experimental Study of Audiovisual Approach in a Course on the Psychology of Creativity. In: Procedia - Social and Behavioral Sciences. 191, 1054-1061. https://doi.org/10.1016/j.sbspro.2015.04.437

Griffin, P. (2017). Assessing and Teaching 21st Century Skills: Collaborative Problem Solving as a Case Study. In: von Davier A., Zhu M., Kyllonen P. (eds) Innovative Assessment of Collaboration. Methodology of Educational Measurement and Assessment. Springer, Cham. https://doi.org/10.1007/978-3-319-33261-1_8

Harding, S. M. E., Griffin, P. E., Awwal, N., Alom, B. M., \& Scoular, C. (2017). Measuring collaborative problem solving using mathematics-based tasks. AERA Open, 3(3), 1-19. 2332858417728046. https://doi.org/10.1177/2332858417728046

Heyman, G. D. (2008). Children's Critical Thinking When Learning from Others. Current directions in psychological science, 17(5), 344-347. https://doi.org/10.1111/j.1467-8721.2008.00603.x

Johnson, D. W., \& Johnson, R. T. (2013). The impact of cooperative, competitive, and individualistic learning environments on achievement. In J. Hattie \& E. Anderman (eds.) International handbook of student achievement (372-374). New York: Routledge. Retrieved from https://www.researchgate.net/publication/260596923_Johnson_D_W_ Johnson_R_T_2013_The_impact_of_cooperative_competitive_and_individualistic_learning_environments_on_ achievement In J Hattie $\overline{\mathrm{E}}$ Anderman Eds International handbook of student achievement 372

Klochko, V. E., \& Galazhinskiy, E. V. (1999). Самореализация личности: системный взәляд [Person self-realization: system view]. Tomsk: Tomsk University Publishing House. Retrieved from http://vital.lib.tsu.ru/vital/access/manager/ Repository/vtls:000112507

Leitz, G. (2017). Психодрама: теория и практика. Классическая психодрама Я.Л. Морено [Psychodrama: theory and practice. Classic psychodrama by Ya.L. Moreno]. Moscow, "Kogito-Center". Retrieved from https://www.klex.ru/18e

Leontiev, A. N. (2004). Деятельность. Сознание. Личность [Activity. Consciousness. Personality]. Moscow: Sense, Academy. Retrieved from https://www.koob.ru/leontjev_a_n/dejatelnost_soznanie_lichnost

Lewin, K. (2019). Теория поля в социальных науках [Field theory in the social sciences]. Moscow, Академический проект. Retrieved from https://www.koob.ru/lewin_kurt/field_theory

Lioe, L. T., Fai, H. K., \& Hedberg, J. G. (2006). Students' Metacognitive Problem-Solving Strategies in Solving Openended Problems in Pairs. In: Redesigning Pedagogy. 243-259. Brill Sense. https://doi.org/10.1163/9789087900977_018

Masten, A. S., \& Obradovic, J. (2008). Disaster preparation and recovery: Lessons from research on resilience in human development. Ecology and Society, 13(1), [9]. https://doi.org/10.5751/ES-02282-130109

Masten, A. S., \& Osofsky, J. D. (2010). Disasters and their impact on child development: Introduction to the special section. Child Development, 81(4), 1029-1039. https://doi.org/10.1111/j.1467-8624.2010.01452.x

Moreno, J. L. (2001). Психодрама [Psychodrama]. Moscow: April Press, EKSMO-Press. Retrieved from https://www.ozon.ru/ product/psihodrama-18090265/?sh=epZqNUlz

Norris, F. H., Stevens, S. P., Pfefferbaum, B. Wyche, K. F., \& Pfefferbaum, R. L. (2008). Community Resilience as a Metaphor, Theory, Set of Capacities, and Strategy for Disaster Readiness. American journal of community psychology. 41, 127150. https://doi.org/10.1007/s10464-007-9156-6

Nurmukhamedova, I. V. (2011). Сравнительный анализ особенностей совместной мыслительной деятельности педагогов на разных этапах школьного обучения [Comparative analysis of the features of the collaborative thinking activity of teachers at different stages of school education. Humanization of education] Гуманизация образования. (6), 26-31. Retrieved from https://cyberleninka.ru/article/n/sravnitelnyy-analiz-osobennostey-sovmestnoy-myslitelnoydeyatelnosti-pedagogov-na-raznyh-etapah-shkolnogo-obucheniya

Osofsky, J. D., Osofsky, H. J., \& Harris, W. W. (2007). Katrina's children: Social policy considerations for children in disasters. Social Policy Report, 21,3-18. https://doi.org/10.1002/j.2379-3988.2007.tb00050.x

Piaget, J. (2001). The Psychology of Intelligence. London: Routledge. Retrieved from https://doi.org/10.4324/9780203164730

Rudestam, K. E. (2006). Групповая психотерапия [Group psychotherapy]. St. Petersburg: Peter. Retrieved from https:// textarchive.ru/c-2065442-pall.html

Suroedova, Е. А. (2019). Структура эмоциональной модальности педагогов с разной стратегией смыслопередачи [Structure of emotional modality of teachers with different strategy of sense transfer. Psychology of learning]. Психология обучения. (6), 103-110. Retrieved from https://www. elibrary.ru/item.asp?id=41435706

Terr, L. C. (1991). Childhood traumas: An outline and overview. The American Journal of Psychiatry, 148(1), 10-20. https://doi. org/10.1176/ajp.148.1.10

Titscher, S., Meyer, M., Wodak, R., \& Vetter, E. (2009). Методы анализа текста и дискурса [Methods of Text and Discourse Analysis]. Humanitarian Centre, Kharkiv, Ukraine. Retrieved from https://studylib.ru/doc/2190201/metody-analizateksta-i-diskursa

Verbitsky, А. А. (2017). История и технологии контекстного образования [History and technologies of contextual education]. Moscow: Moscow State Pedagogical University. Retrieved from https://www.iprbookshop.ru/72517.html

Vygotsky, L. S. (2005). Психология развития человека [Human developmental psychology]. Moscow: Smysl; Eksmo. Retrieved from http://lchc.ucsd.edu/mca/Mail/xmcamail.2008_07.dir/att-0052/problema_razvitiya_i_raspada_vysshih_ psih_funkciy.pdf

Yalom, I. (2001). Групповая психотерапия: теория и практика [Group psychotherapy: theory and practice]. Moscow: April Press. Retrieved from https://www.klex.ru/5jg

Yuan, J., Xiao, Y., \& Liu, H. (2019). Assessment of Collaborative Problem Solving Based on Process Stream Data: A New Paradigm for Extracting Indicators and Modeling Dyad Data. Frontiers in Psychology, 10, 369. https://doi.org/10.3389/ fpsyg.2019.00369

Yul, U., \& Williams, R.M. (1992). An intervention strategy for mental trauma resulting from large-scale disasters. n: Lane, D.A., Miller, A. (eds) Child and adolescent psychotherapy. Buckingham Philadelphia, Open University Press. 275-308. https://archive.org/details/childadolescentt0000unse_a9e4 